\title{
Comparison of different maize stalk sources in China's dairy production based on the Cornell system $^{*}$
}

\author{
J.S. Zhao, Y.Q. Xiong, J.P. Du and Q.X. Meng1 \\ State Key Laboratory of Animal Nutrition, Beef Cattle Research Centre, \\ College of Animal Sciences \& Technology, China Agricultural University \\ Beijing 100094, P.R. China
}

\begin{abstract}
For optimising the use of maize stalks in China's dairy production system, dry maize stalks (DMS), maize stalk silage (MSS) and high oil maize silage (HOMSS) were compared at 11 concentrate/ roughage (C/R) levels from $25 / 75$ to $75 / 25$ with maize stalks used as a sole roughage source in the TMR. The Cornell system V5.0 was used as the base model in computer simulation. Actual chemical analyses of DMS, MSS and HOMSS were used in feed database. Results indicated that the HOMSS, MSS and DMS based TMR supported milk yield up to 28,25 and $23 \mathrm{~kg} / \mathrm{d}$, respectively. At the same $\mathrm{C} / \mathrm{R}$ level, HOMSS supported the highest milk yield with the highest economic return and the lowest concentrate consumption and the lowest $\mathrm{N}$ excretion per kg of milk. DMS supported the lowest milk yield with the lowest economic return, the highest concentrate consumption and the highest $\mathrm{N}$ excretion per kg of milk.
\end{abstract}

KEY WORDS: maize stalk, Cornell system, dairy production system

\section{INTRODUCTION}

Due to limited arable land, maize stalks have been the predominant roughage source for dairy and beef cattle in some major crop production areas in China. The traditional way of feeding maize stalks was feeding them in the sun-cured form (dry maize stalks, DMS). Nutrient loss caused by spoilage, leaching and leaf loss during handling is unavoidable. Besides, year-round supply of dry stalks is difficult. Ensilage upon ear-pick-up (maize stalk silage, MSS) will overcome most the above problems. It has been found that the high oil maize stalk contains

\footnotetext{
* Supported by China Ministry of Agriculture 948 Project No. 2006-G47

${ }^{1}$ Corresponding author: e-mail: qxmeng@cau.edu.cn
} 
significantly higher amount of available nutrients (LaCount et al., 1995; Dhiman et al., 1996; Zhao, 2003; Yan, 2005; Dong, 2006). In addition, high oil maize keeps the plant green and succulent much longer in the field after ears are harvested, which is favourable for silage making.

The Cornell Net Carbohydrate and Protein System (CNCPS) has a biologically based structure, permitting prediction of nutrient requirements, feed utilization and animal performance over wide ranges in cattle, feed, management and environmental conditions (Fox et al., 1992, 2000; Tylutki and Fox, 1998; Molina et al., 2004; Zhao et al., 2007). Thus, the CNCPS provides a powerful tool in computer simulation.

The objective of the present study was to use the CNCPS version 5.0 as a base model to compare DMS, MSS and HOMSS for optimizing the use of maize stalks in China's dairy feeding system.

\section{MATERIAL AND METHODS}

Listed in Table 1 are average values for animal, environment and management factors set as inputs into the CNCPS model for simulations. One of the three maize stalks (treatments: DMS, MSS and HOMSS) was sole roughage sources for individual diets. Eleven simulations were conducted for each treatment with roughage/concentrate ratio (C/R) of 75/25, 70/30, 65/35, 60/40, 55/45, 50/50, 45/55, $40 / 60,35 / 65,30 / 70$ and $25 / 75$. Feed ingredients for formulation of the concentrate portion were those commonly available in North China area (Table 2).

Table 1. Inputs used for the Cornell Net Carbohydrate and Protein System simulation

\begin{tabular}{lcll}
\hline \multicolumn{2}{c}{ Animal description } & \multicolumn{2}{c}{ Management and environment } \\
\hline Number in group & 80 & Additive & None \\
Days to feed & 30 days & Added fat & None \\
Age of animals & $40 \mathrm{months}$ & Wind speed & $1.6 \mathrm{kph}$ \\
Body weight & $600 \mathrm{~kg}$ & Prev. temperature & $15.6 \mathrm{deg}$. C. \\
Days pregnant & $30 \mathrm{days}$ & Prev. relative humidity & $40 \%$ \\
Days since calving & 94 days & Current temperature & $15.6 \mathrm{deg}$. C. \\
Lactation number & 2 & Current relative humidity & $40 \%$ \\
Calving interval & 12.5 months & Hours in sunlight & $0 \mathrm{~h}$ \\
Expected calf birth weight & $43 \mathrm{~kg}$ & Storm exposure & None \\
Age at first calving & $22 \mathrm{months}$ & Hair depth & $0.64 \mathrm{~cm}$ \\
Milk fat & $3.5 \%$ & Mud depth & $0 \mathrm{~cm}$ \\
Milk protein & $3.23 \%$ & Hair coat & No mud \\
Condition score & 2.6 & Cattle panting & None \\
Breed & Holstein & Minimum night temperature & 10 deg. C. \\
& & Activity & Large free-stalls \\
\hline
\end{tabular}


TMR diets were formulated least costly based on CNCPS prediction as such: 1. the supplied ME, MP, Met Lys, Ca, P, K were balanced for animal total requirements, and 2. rumen nitrogen was maintained at a positive balance. At $75 \%$ concentrate level, soyabean hulls inclusion level reached $27 \%$ of the TMR to meet the NDF requirement $(\mathrm{NDF}>23 \%)$.

The following predicted results were recorded for each group of animals: 1 . milk yield that the diet was able to support, 2. the cost per $\mathrm{kg}$ milk, 3 . gross income per head animal (milk sale minus feed costs), and 4. total nitrogen excretion per kg milk.

Table 2. Diets used in the Cornell Net Carbohydrate and Protein System simulation

\begin{tabular}{lcccccccccccc}
\hline Concentrate/roughage & $25 / 75$ & $30 / 70$ & $35 / 65$ & $40 / 60$ & $45 / 55$ & $50 / 50$ & $55 / 45$ & $60 / 40$ & $65 / 30$ & $70 / 30$ & $75 / 25$ \\
\hline Ingredients, \% & & & & & & & & & & & & \\
$\quad$ maize grain & 0 & 1 & 2.5 & 4.3 & 6 & 9 & 12 & 15.7 & 17.5 & 23 & 27 \\
soyabean meal & 18.5 & 18.5 & 17 & 16 & 16 & 13.5 & 12.5 & 11 & 9 & 10 & 6.5 \\
cottonseed meal & 4 & 4.5 & 5 & 5.2 & 5 & 6.5 & 7 & 7.8 & 8.5 & 8 & 10 \\
soyabean hulls & 0 & 3.5 & 8 & 11.5 & 15 & 18 & 20.5 & 22 & 26.5 & 24.5 & 27 \\
limestone & 0.5 & 0.5 & 0.5 & 0.5 & 0.5 & 0.5 & 0.5 & 0.5 & 0.5 & 0.5 & 0.5 \\
calcium phosphate & 0.5 & 0.5 & 0.5 & 0.5 & 0.5 & 0.5 & 0.5 & 0.5 & 0.5 & 0.5 & 0.5 \\
premix & 1 & 1 & 1 & 1 & 1 & 1 & 1 & 1 & 1 & 1 & 1 \\
salt & 0.5 & 0.5 & 0.5 & 0.5 & 0.5 & 0.5 & 0.5 & 0.5 & 0.5 & 0.5 & 0.5 \\
bicarbonate sodium & 0 & 0 & 0 & 0.5 & 0.5 & 0.5 & 0.5 & 1 & 1 & 2 & 2 \\
$\quad$ maize stalks & 75 & 70 & 65 & 60 & 55 & 50 & 45 & 40 & 35 & 30 & 25 \\
Total & 100 & 100 & 100 & 100 & 100 & 100 & 100 & 100 & 100 & 100 & 100 \\
\hline
\end{tabular}

Nutrient compositions of DMS, MSS and HOMSS entered into the CNCPS V 5.0 User-Created Feed Database were primarily based on our lab analyses from samples collected from dairy farms in north China area (Table 3). The price of feed ingredients was based on the average market values. A premium of 40 Yuan /ton was added to MSS as processing costs for ensilage to ensure that DMS was not undervalued. An artificially assumed additional premium of 100 Yuan/ton was added to HOMSS in order to encourage farmers to grow high oil corn (Table 3).

\section{RESULTS AND DISCUSSION}

The average DMI (dry matter intake) and milk yield of each simulation were shown in Figure 1. DMI and the milk yield of the HOMSS treatment were significantly higher than the others at each $\mathrm{C} / \mathrm{R}$ ratio. About $4.5-6 \mathrm{~kg} /$ day higher milk yield that HOMSS can support than does MSS at the same TMR diet. It also suggests that both DMS and MSS rations support more than $22 \mathrm{~kg}$ milk yield if up to $75 \%$ concentrate for more than $27 \%$ soyabean hulls were included in the TMR. 
Table 3. Composition and price of dry maize stalk (DMS), maize stalk silage (MSS) and high oil maize stalk silage (HOMSS)

\begin{tabular}{lrrr}
\hline Item & DMS & MSS & HOMSS \\
\hline DM, \% & 60.00 & 30.38 & 27.58 \\
NDF, \%DM & 72.00 & 66.99 & 61.18 \\
Lignin, \%NDF & 10.00 & 10.00 & 7.00 \\
CP, \%DM & 5.14 & 6.58 & 7.94 \\
Starch, \%NSC & 35.00 & 45.00 & 59.00 \\
Fat, \%DM & 1.48 & 1.48 & 2.59 \\
Ash, \%DM & 7.20 & 9.00 & 8.80 \\
Physically effective fibre, \%NDF & 100.00 & 95.00 & 85.00 \\
Soluble-protein, \%CP & 20.00 & 45.00 & 50.00 \\
NPN, \%Sol-P & 95.00 & 100.00 & 100.00 \\
NDF, \%CP & 31.43 & 16.00 & 16.40 \\
ADF, \%CP & 13.57 & 4.50 & 7.88 \\
Price, yuan/ton & & & 200.0 \\
\hline
\end{tabular}

Regression equations predicting percent of concentrate in the TMR (Yc) from milk production $(\mathrm{Xm})$ for each stalk source are listed below:

$$
\begin{array}{ll}
\text { DMS: } & \text { Ycd }=0.037 \mathrm{Xmd}-0.121\left(\mathrm{R}^{2}=0.998, \mathrm{P}<0.0001\right), \\
\text { MSS: } & \text { Ycm }=0.044 \mathrm{Xmc}-0.346\left(\mathrm{R}^{2}=0.999, \mathrm{P}<0.0001\right), \\
\text { HOMSS: } & \text { Ych }=0.064 \mathrm{Xmh}-1.049\left(\mathrm{R}^{2}=0.994, \mathrm{P}<0.0001\right) .
\end{array}
$$

With such high $\mathrm{R}^{2}$ and $\mathrm{P}$ values, the concentrate level in TMR should be well predicted based on the milk yield. At a current typical milk yield level of $20 \mathrm{~kg} /$ day, the predicted concentrate levels in TMR are 61.9, 53.4 and 23.1\% for DMS (Ycd), MSS (Ycm) and HOMSS (Ych), respectively. At same milk production level, animals fed with MSS based TMR consume less concentrate than with DMS based TMR. HOMSS based TMR consumes less concentrate than does MSS based TMR. This is very important for a farming-land-limiting country such as China.
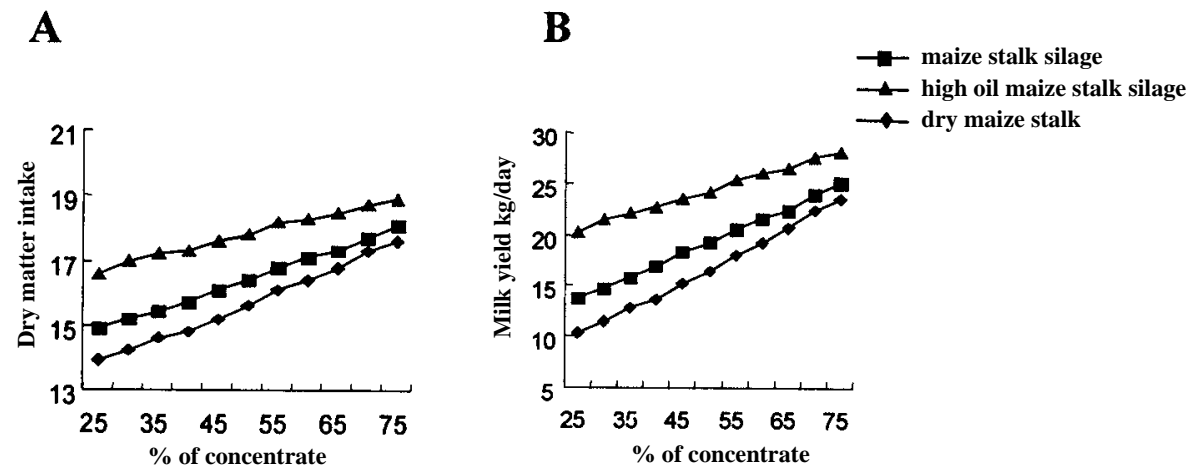

Figure 1. The DMI and milk yield of the cows in three treatments 

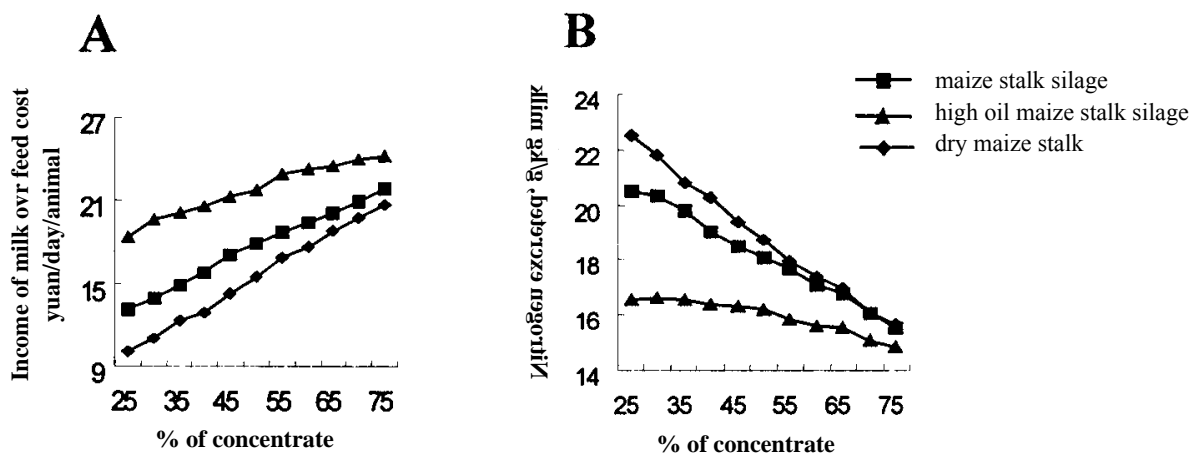

Figure 2. A. Income of milk over feed cost per animal. B. Nitrogen excretion per $\mathrm{kg}$ milk

The average results of income for each simulation are showed in Figure 2A. It suggests that although the price of HOMSS was set significantly higher, HOMSS based TMR still brought the highest income. MSS based TMR brought more income than did DMS. As showed in Figure 2B, the nitrogen excretion of HOMSS was much lower than the other two treatments. MSS excreted less nitrogen than did DMS. Making silage is not only a good way to preserve the maize stalks, but also can be more profitable and minimizing the nitrogen excretion.

\section{CONCLUSIONS}

Maize stalks can be well used for dairy production especially under conditions where farming land is limited such as in China. Dry maize stalk ration can support about $12-23 \mathrm{~kg}$ milk in this research (see Figure 1B). Silage making is a much better way to utilize maize stalks. High oil maize is the best choice for future use in China.

\section{REFERENCES}

Dhiman T.R., Hoogendijk B., Walgenbach R.P., Satter L.D., 1996. Feeding high oil maize to lactating dairy cows. J. Dairy Sci. 79, Suppl. 1, 136 (Abstr.)

Dong X., 2006. A study into the effect of maize hybrids, buffer propionic acid and producing propionic acid bacteria on fermentation in silage. PhD. Dissertation, China Agricultural University

Fox D.G., Sniffen C.J., O'Connor J.D., Russell J.B., Van Soest P.J., 1992. A net carbohydrate and protein system for evaluating cattle diets. III. Cattle diets and diet adequacy. J. Anim. Sci. 70, 3578-3596

Fox D.G., Tylutki T.P., Van Amburgh M.E., Chase L.E., Pell A.N., Overton T.R., Tedeschi L.O., Rasmussen C.N., Durbal V.M., 2000. The Net Carbohydrate and Protein System for Evaluating Herd Nutrition and Nutrient Excretion: Model Documentation. Ithaca, NY, pp. 41-82 
LaCount D.W., Drackley J.K., Cicela T.M., Clark J.H., 1995. High oil maize as silage or grain for dairy cows during an entire lactation. J. Dairy Sci. 78, 1745-1754

Molina D.O., Matamoros I., Almeida Z., Tedeschi L., Pell A.N., 2004. Evaluation of the dry matter intake predictions of the Cornell Net Carbohydrate and Protein System with Holstein and dualpurpose lactating cattle in the tropics. Anim Feed Sci. Tech. 114, 261-278

Tylutki T.P., Fox D.G., 1998. Dairy farming and water quality: II. Whole farm nutrient management planing. Proceedings Northeast Agricultural Engineering Service, Dairy Feeding Systems Conference, pp. 345-358

Yan G., 2005. Botanical factors affecting the nutritional value of crop residues and the effectiveness of their treatment with chemical combinations. PhD. Dissertation, China Agricultural University

Zhao J.S., Zhou Z.M., Ren L.P., Xiong Y.Q. Meng Q.X., 2007. Evaluate of dry matter intake and daily weight gain predictions of the Cornell net carbohydrate and protein system with local beef cattle breeds in China. Anim. Feed Sci. Tech. (accepted)

Zhao Z.Y., 2003. Interaction between variety and maturity stage of kernels to affect silage fermentation characteristics of high oil maize stalks and their feeding value to growing cattle. M.S. Dissertation, China Agricultural University 